\title{
A 'Melting Pot' City: Migration and Municipality in the Reconstruction of Dortmund
}

\author{
Brian Shaev \\ Institute for History, Leiden University, Leiden, The Netherlands \\ b.shaev@hum.leidenuniv.nl
}

\begin{abstract}
This article explores how Dortmund's municipal government propagated a concept of city-citizenship and belonging for new arrivals by mediating between expellee, refugee and migrant communities and 'native' civil society in the 1940s-1950s. The devastation of Dortmund during the Second World War, and the housing and energy shortages that followed, meant that the arrival of over a hundred thousand expellees and refugees in 1945-196o placed severe strains on municipal resources while exacerbating conflicts between 'native' Dortmunders and new arrivals. The success of the Social Democratic Party (SPD) in building a hegemonic position in postwar politics and administration by the late 1940 s facilitated the coordination of municipal efforts to foster intercommunity relations and introduce new populations to city life. Within the city council and government, in expellee meetings, and in municipal events we observe sustained municipal efforts to 1 ) exert social control over expellee/refugee arrivals to deflect anger at the poor conditions of the reconstruction period away from municipal officials and 2) inculcate taboos based on peace and democratic norms to delegitimise the politics of inter-community resentment. It concludes by tracing how official narratives and municipal practices constructed in the 1940s-50s were redeployed during the arrival of guest workers in the 196os.
\end{abstract}

\section{Keywords}

expellees - refugees - guest workers - integration - reconstruction - social democracy - heavy industry - deindustrialisation 


\section{Introduction}

In March 1950, Dortmund's city bulletin celebrated the birth of a baby girl in an article titled 'Dortmund has again its 500,oooth inhabitant.' Born to a family of 'refugees' with a name of Polish origin that had arrived in Dortmund in 1946, her father followed previous generations of migrants in taking a job at a local coal pit. The visit coincided with a semantic shift in the Federal Republic of Germany, as the term 'expellee' gained ground to differentiate migrants who had been forced to leave Central-Eastern Europe and 'refugees' whose reasons for migration were more diverse and open to (mis)interpretation. ${ }^{2}$ The baby's family had a hard story all too common in the era's history of displacement and expulsion. Two children had died during their journey west and a third later died of infection. The newborn was the family's fourth child. City officials used the birthday to celebrate the child - a child of migrants - as symbol of Dortmund's postwar rebirth. The city director's wife and a local official personally delivered a message on behalf of mayor Fritz Henssler. They expressed their

wish [that] there $[\ldots]$ be no difference at all in the handling of old and new citizens. [We] consider the Eastern refugees who came to Dortmund to be full-fledged citizens of the city and want them to look at Dortmund as their home city.

This visit began a local tradition. Into the 1960s, officials visited on her birthday, delivering the city's best wishes and, of course, presents. ${ }^{3}$

Large-scale migration to Dortmund after the Second World War comprised returnees evacuated during the war, expellees initially lodged in temporary camps in Schleswig-Holstein and later in Siegen, and illegal border-crossers from the Soviet zone, later renamed Soviet-Zone refugees. They arrived to a city devastated by war, with its inhabitable housing stock halved from pre-war numbers. The British occupation requisitioned housing in Dortmund as elsewhere in Westphalia, thereby evicting locals. A local organisation (Notgemeinschaft der Besatzungsgeschädigten) formed to pressure German

1 'Dortmund hat wieder 500 ooo Einwohner', Verwaltungsbericht, 23 March 1950. Verwaltungsbericht was Dortmund's municipally-run newspaper.

2 Iris Nachum and Sagi Schaefer, 'The semantics of political integration: public debates about the term "expellees" in post-war Western Germany', Contemporary European History 27:1 (2018) $42-58$.

3 '500 oooster Dortmunderin 12 Jahre alt', Verwaltungsbericht, 16 March 1962. 
and occupation authorities to restore requisitioned property. ${ }^{4}$ Henssler also petitioned to house coal miners in former military barracks occupied by British soldiers. ${ }^{5}$ Housing destruction presented much larger problems than requisitioning though. Chronic housing shortages spanned the entire postwar era. There are no official numbers of returnees, but their number was at least in the tens of thousands, despite an official ban on return from 1946 as city officials coped with large-scale refugee arrivals and privileged entrance for qualified workers in reconstruction industries. Estimates of Dortmund's expellee population in 1959 were 80,000 and Soviet-Zone refugees 53,000 (note: these city statistics are rough estimates). ${ }^{6}$ In 1961 Dortmund's Social Office estimated expellee numbers at 102,000. Dortmund received the highest proportion of Soviet-Zone refugees in North-Rhine-Westphalia (NRW); ${ }^{7}$ by contrast it only received several dozen Hungarian refugees in 1956. Dortmund was slow to receive guestworkers, with estimates of 16,700 in 1963, 2.4 per cent of Dortmund's population. ${ }^{8}$ The total proportion of expellees and refugees living in Dortmund increased from 9.8 per cent in 1948 to 25 per cent in 1961, a year after guestworkers first arrived. ${ }^{9}$ There was also a new Polish population (among the estimated 83,000 displaced Poles in the British occupation zone), but there are no local estimates beyond a settlement for former Displaced Persons (DP s) in Eving, Dortmund's northern suburb, where 200 mostly Polish families arrived in $1950-510^{10}$ These categorisations had real consequences because legal rights and social assistance depended on them but they were not self-evident. It is not clear, for instance, whether the newborn's family had the legal status of expellees, refugees, former DP s, or Polish emigrants.

Recent case studies of migrant policies in European cities and comparative migration research have come to a general consensus that the local dimension

4 Bettina Blum, “My home, your castle”: British requisitioning of German homes in Westphalia', in: Camilo Erlichmann and Christopher Knowles (eds.), Transforming occupation in the Western Zones of Germany: Politics, everyday life and social interactions, 1945-55 (London 2019) 115-32, 119 .

5 Stadtarchiv Dortmund (SD), 90 5\%/1, Niederschrift über die Stadtvertretersitzung am 25·3.1947.

6 'Weltflüchtlingssammlung', Verwaltungsbericht, 3 September 1959.

7 Westfälisches Wirtschaftsarchiv Dortmund (wWD), K1 30.151, Niederschrift über die Sitzung der Vertriebenenbeirates in Dortmund am 19.10.1953.

8 SD, 9o/o1 8, Niederschrift über die 17. öffentliche Sitzung des Rates der Stadt am Montag, dem 17. Dezember 1962.

$9 \quad$ 'Ingenieur Paul Klambt nahm Abschied', Verwaltungsbericht, 7 July 1961.

10 Gabriele Dietz-Görrig, 'Displaced Persons. Ihre Integration in Wirtschaft und Gesellschaft des Landes Nordrhein-Westfalen', dissertation Universität Düsseldorf (Düsseldorf 1992) 11. 
of migration policymaking matters."11 Michael Alexander in his seminal article on host-stranger relations argues that local authorities' 'prevailing attitudes' often drive local migrant policies while Teresa Cappiali argues that 'ideology matters in predicting how local actors promote integration.' ${ }^{2}$ Others claim that local-level policies tend to be more pragmatic responses to problems than ideologically-driven. ${ }^{13}$ Scholars agree though, that the way local actors 'frame' migration significantly affects the policies adopted and implemented. Following Tiziana Caponio, this article explores the 'local policy arena' of migrant reception and integration in Dortmund by examining the interrelation of politicians, bureaucrats, and civil society. ${ }^{14}$ To capture the dynamics of this interaction, the article also draws inspiration from interdisciplinary research on the governance of migration in cities to explore legacies of migration histories, city policies from bottom-up and top-down perspectives, policy responses and networks, and social and political constructions of city identities. ${ }^{15}$ These approaches are paired with a vigorous analysis of archival sources of the city council, Dortmund administrative offices, the advisory Expellee and Refugee Committee, the local Chamber of Commerce, North-Rhine-Westphalian state records, the city bulletin, and local newspapers.

This article explores how Dortmund officials negotiated a postwar concept of city-citizenship and belonging for new arrivals by mediating between expellee, refugee and migrant communities and 'native' civil society in the 1940s-195os. It argues that an inclusive and non-ethnicised discourse of city-level integration contributed to a municipal democratisation project that sought to bind new and old residents together in discourses of shared suffering and mutual obligation. The war-time devastation of Dortmund, and the hunger and severe housing and energy shortages that followed, meant that the

11 Maren Borkert and Tiziana Caponio, 'Introduction', in: T. Caponio and M. Borkert (eds), The local dimension of migration policymaking (Amsterdam 2010) 9-31.

12 Michael Alexander, 'Local policies towards migrants as an expression of Host-Stranger relations: A proposed typology', Journal of Ethnic and Migration Studies 29:3 (2003) 41130; Teresa M. Cappiali, 'How do local actors promote civic participation of immigrants? Approaches to integration and local dynamics', in: Tiziana Caponio, Peter Scholten and Ricard Zapata-Barrero (eds), The Routledge handbook of the governance of migration and diversity in cities (Abingdon 2019) 116-129, 118.

13 Christophe Bertossi and Jan Willem Duyvendak, 'National models of immigrant integration: the costs for comparative research', Comparative European Politics 10:3 (2012) 237-247.

14 Tiziana Caponio, 'Conclusion: making sense of local migration policy arenas', in: Caponio and Borkert (eds), The local dimension of Migration Policymaking, 161-192.

15 Tiziana Caponio, Peter Scholten, and Ricard Zapata-Barrero, 'Introduction', in: Caponio et al., The Routledge handbook of the governance of migration and diversity in cities (Abingdon 2019) $1-7$. 
arrival of over a hundred-thousand expellees and refugees in 1945-196o placed severe strains on municipal resources while exacerbating conflicts between 'native' Dortmunders and new arrivals. In a local context of extended postwar crisis, officials perceived expellee and refugee arrivals as an enormous burden.

'Success stories' of postwar expellee integration as comparatively smooth because of their 'German' background have long segregated expellee history from other migration histories of Germany. Recent historiography challenges this separation. Philipp Ther writes that 'For a long time, the expellees' integration was viewed far too positively' while Iris Nachum and Sagi Schaeffer argue that 'the public in the Western zones of occupation was reluctant to accept the idea that they were indeed to be seen as permanent additions to German society'. ${ }^{16}$ Similarly, Rainer Schulze writes of 'rising tensions between locals and newcomers' and that 'rejection and exclusion soon dominated.' ${ }^{17}$ Here we explore societal tensions in war-stricken Dortmund and how the city proactively sought to lessen the bases of inter-community conflict during its reconstruction. The welcoming and inclusive rhetoric developed by Dortmund officials was later redeployed towards guest workers in the 196os-a finding that suggests not only that expellees should be included in histories of migration to Germany, but that the experience of expellee integration directly affected the early politics on guestworkers in Dortmund.

The Social Democratic Party (SPD) built a near-hegemonic position in postwar Dortmund by the late 1940s. That the local Christian Democratic Party (CDU) supported its welcoming policies for expellees and refugees, facilitated a local consensus. The municipality built cohesive policies to introduce new populations to city life in the fields of housing, education and labour markets. The analysis accords with what Patrick Ireland finds for a later period in the neighbouring Ruhr city of Essen, where the Ruhr's 'melting-pot' historical identity informed local policies 'the underlying logic [of which] was decidedly social democratic, centred on individual rights and working-class identity.18 It also bears similarities to social-democratic-controlled Bremen, which Sarah Hackett demonstrates mobilised a working-class historical identity to

16 Philipp Ther, "The integration of expellees in Germany and Poland after World War II: A historical reassessment', Slavic Review 55:4 (1996) 779-805; Nachum and Schaefer, 'The semantics of political integration'.

17 Rainer Schulze, 'Forced migration of German populations during and after the Second World War: History and memory', in: Jessica Reinisch and Elizabeth White (eds), The disentanglement of populations: migration, expulsion and displacement in post-war Europe, 1944-9 (Basingstoke 2011) 51-70.

18 Patrick Ireland, Becoming Europe: Immigration integration and the welfare state (Pittsburgh 2004) 66. 
proactively integrate guest workers and their families into city life. ${ }^{19}$ Ideology also mattered for migrant reception in Dortmund, where city officials constructed a self-identity of Dortmund as a working-class city built by previous generations of migrants. In their interactions with expellees and new arrivals we observe sustained municipal efforts to exert social control not only to deflect anger rooted in frustrations at poor housing and social conditions away from municipal officials but also to inculcate a set of taboos based on peace and democratic norms to delegitimise the politics of inter-community resentment. When guestworkers arrived in Dortmund in the 196os, city leaders extended welcoming city narratives to new populations, but the postwar concept of city-citizenship now came under strain as the presence of foreign 'guests' opened up new grounds for contestation of what it meant to be a Dortmunder in the 196os.

\section{Reconstruction Dortmund: Migration to a Devastated City}

Postwar Dortmund faced harrowing housing and social conditions that continued into the 1950s. In 1939 Dortmund had an estimated 540,00o residents and 140,00o dwellings. About 70,000 of these, estimated to have housed 300,000 residents, were destroyed during the Second World War. This does not capture the full picture. The city condemned a hefty proportion of what remained as uninhabitable, such that Henssler estimated inhabitable dwellings in 1945 to have been as low as 43,000. ${ }^{20}$ This number rose to 69 ,00o by 1947 but was still woefully inadequate for arriving expellee and refugee populations, let alone to prepare for a return of Dortmund's war-time 'evacuees'. The initial postwar housing programme was makeshift: schools, guesthouses, and other structures were requisitioned to serve as temporary shelters along with barracks. Conditions in inner-city shelters-within Dortmund's Ringstrasse-were especially dismal. There was a rush to construct emergency camps as well as long-term refugee camps in Dortmund's outskirts to house thousands of yearly arrivals, in particular in the districts of Brackel, Eving and Lütgendortmund, bordering on northeastern Bochum.

19 Sarah Hackett, Foreigners, minorities, and integration: The Muslim immigrant experience in Britain and Germany (Manchester 2013) 190-221.

20 SD, 90 5o/1, Niederschrift über die öffentliche Stadtvertretersitzung am 24.6.1947. 


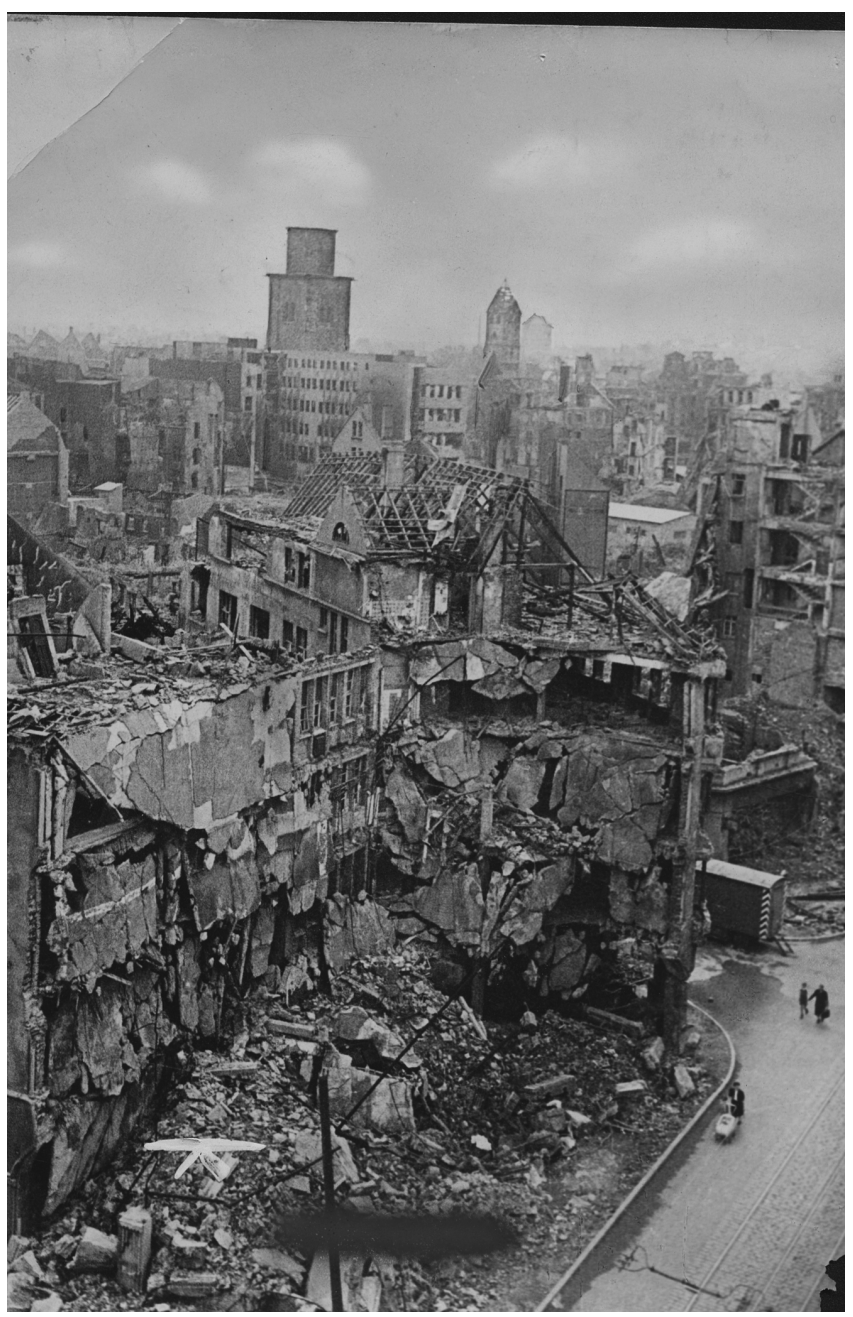

FIGURE 1 View of central Dortmund from the tower of the Reinoldi Church. Courtesy of Dortmund city archive, used with permission.

A city welfare committee in July 1945, right after the war, declared a 'pressing need to ban return-migration. ${ }^{21}$ The city anticipated with forbearance the return of 20,000 school-age children evacuated to Bavaria and families in Baden at the same time that expellee and refugee transports were arriving from the east. ${ }^{22}$ In 1946 Dortmund enacted a 'migration stop,' which was only

21 SD, Niederschrift über die Sitzung des Überleitungsausschusses bei der Stadtverwaltung Dortmund am 11.7.1945.

22 SD, Niederschrift über die Sitzung des Stadtausschusses am 10.10.45. 
gradually relaxed after 1949, but the city only had authority over the entrance of non-expellee and non-refugee populations. The city received two transports from Silesia, newly annexed to Poland, of over a thousand expellees in 1946, which mushroomed into an estimated 17,00o refugees and expellees in Dortmund by 1947. These numbers continued to grow. An estimated 18,ooo new arrivals came yearly to Dortmund in $1947-53$, of which an estimated 6o,ooo were expellees and refugees.

New arrivals came to a city experiencing chronic labour shortages but their qualifications were often poor matches for local industry needs. Dortmund and neighbouring cities were central to postwar reconstruction efforts not only in the Federal Republic but in Europe as a whole. The Ruhr was an object of international tensions, culminating in the 1950 Schuman Plan for a FrenchGerman entente on managing European heavy industry. ${ }^{23}$ Its mono-industrial economy was heavily tilted towards coal, steel, iron, and construction, though Dortmund also had important breweries and some electronic companies. In 1950-before the postwar boom led to full employment in GermanyDortmund had the lowest official unemployment rate in NRW at 3.2 per cent. ${ }^{24}$ Despite this tight labour market, municipal officials fretted over incoming migration due to chronic food, housing and energy shortages. ${ }^{25}$ They lobbied the NRW government to keep arrivals low and limit entry to working-aged people essential for reconstruction industries. Dortmund's Housing Office published a notice in 1948 that:

To all people who do not have an obligatory reason to come to Dortmund, we ask again:

Remain where you are, do not come to Dortmund! By doing so you will help a city heavily damaged by the bombing war in its hardest of times. ${ }^{26}$

This context was rife for resentment between an often-hungry and ill-housed local population, including natives eager to reunite with evacuated family members, and new populations of refugees and expellees, who had legal preference for housing and social services. As late as 1950 the municipality was

23 Brian Shaev, 'Workers' politics, the Communist challenge, and the Schuman Plan: A comparative history of the French Socialist and German Social Democratic Parties and the first Treaty for European Integration', International Review of Social History 61:2 (2016): $251-281$.

24 SD, 9o/o1 2/2, Niederschrift Ratsversammlung, 6.5.1950.

25 Christoph Klessmann and Peter Friedemann, Streiks und Hungermärsche im Ruhrgebiet 1946-1948 (Frankfurt a.M. 1977).

26 'Weiterhin Zuzugsverbot für Dortmund!' Bekanntmachungen, 2 March 1948. 


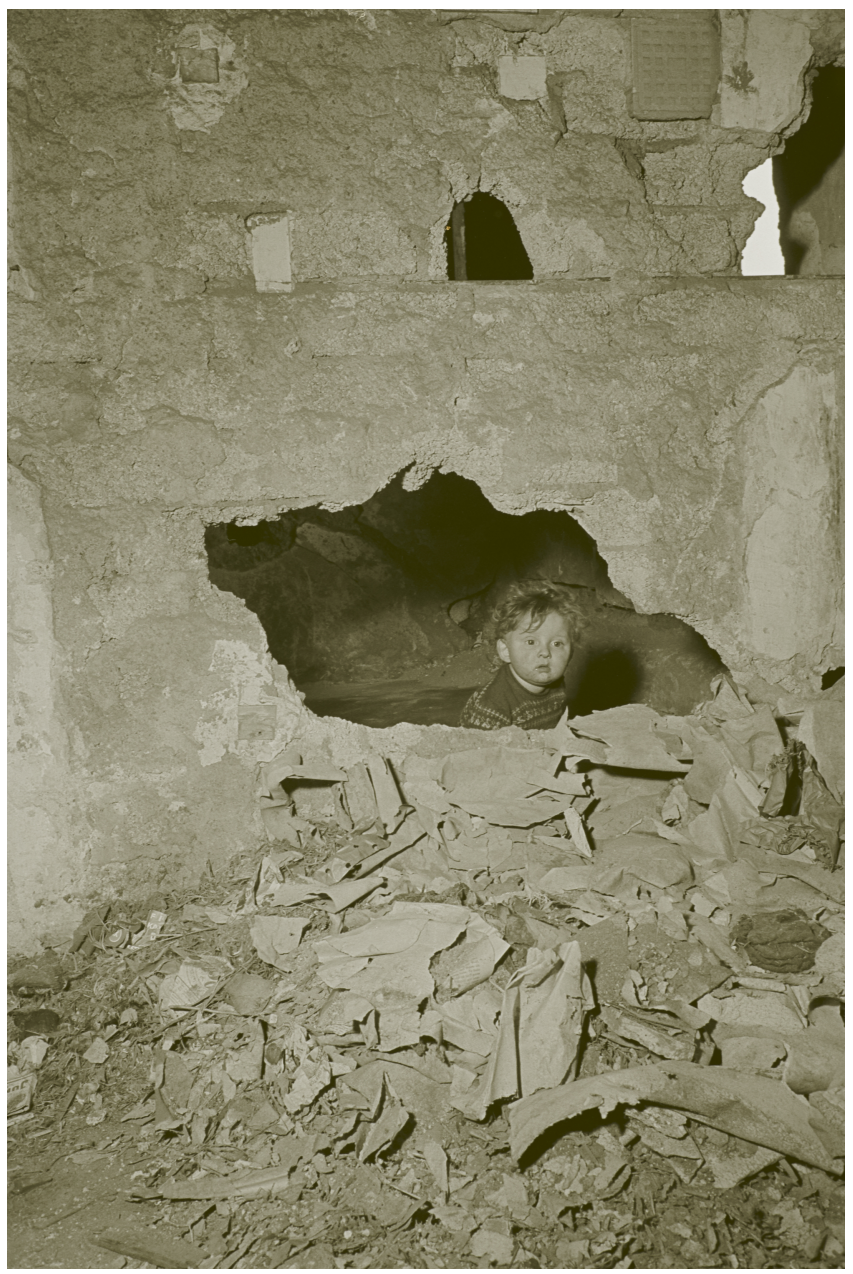

FIGURE 2 An inhabited house in Dortmund destroyed by bombs, August 1954. Courtesy of Dortmund City Archive, used with permission.

rejecting an estimated 40 per cent of applications from people who requested to come (or return) to Dortmund. The city set up a service office for returnees' 're-integration' attached to the invalidity and war victims department of Dortmund's Social Office. ${ }^{27}$ Expellees, returnees and labour migrants often competed for scarce housing; the city tried to ensure that companies recruiting labour provided housing but the city had to designate who among the populations in need would receive newly constructed accommodations. Hoesch and other local industrial companies took the lead in housing non-refugee

27 SD, 100/53, Änderung der Richtlininen, 24.1.1947. 
labour migrants in the North End of Dortmund, a traditional settlement area for labour migrants.

When the Federal Republic opened in 1949, the municipal government, now completely dominated by Social Democrats, determined that workers would not be able to pay the cost of housing reconstruction. ${ }^{28}$ It launched an ambitious housing programme that devoted enormous sums to complement state and federal funding. To illustrate this: in 1957 public funds financed 71.9 per cent of housing construction in Dortmund, whereas the West German average was 49 per cent. ${ }^{29}$ This was a response to social crisis. The vast majority of new postwar arrivals - and returnees whose homes had been destroyedlived in emergency shelters and collective housing. ${ }^{30}$ Dortmund's Social Office later expressed how dire postwar conditions had been: 'We should not forget what legislators understood by the term 'shelter' [Unterkunft]. In practice this mean[t] only a roof over the head and four walls,' though even this was too generous a description for some 'shelters,' which included various forms of open-air housing. Thousands also lived in dangerous proximity to people with tuberculosis. In 1950 Dortmund's Housing Office announced that new arrivals would receive appropriate housing within 6 months. This goal was not met but housing reconstruction gained pace in the early 1950 os.

Inter-community disputes over material resources, public space, and the 'privileging' of certain groups afflicted reconstruction-era Dortmund. Daily-life frustrations came out prominently in the Expellee Committee (Vertriebenenbeirat) established in 1947 to advise the city government. In these meetings city officials, expellee elected representatives, and charity, religious, employer and trade-union groups met to discuss civic integration in Dortmund (invited groups included Caritas, Inneren Mission, the Red Cross, Kreisvereinigung der Ostvertriebenen, Verband der Ostzonenflüchtlinge, the DGB trade union, Industrie, Handelskammer und Handwerksammer, the Jewish community, and Verband der Landmannschaften). The Expellee Committee focused on provisioning, legal matters, culture, and arrival—and contesting cases in which the city refused entry to refugees who did not fall under the resettlement procedures of German and occupation authorities. ${ }^{31}$

There expellees vented to city officials of inadequate assistance and their treatment in daily interactions with native Dortmunders. A mediation

\footnotetext{
28 SD, 100/82, Referat, Die Notwendigkeit des sozialen Wohnungsbaues, 7 March 1949.

29 'Die Wohnungsplan im Jahre 1956', Verwaltungsbericht, 21 June 1957.

30 'Menschen in Not und Bedrängnis: Die Hilfe durch das Städtische Wohlfahrts- und Jugendamt', Bekanntmachungen, 10 August 1948.

$3^{1}$ SD, 100/50, Niederschrift über die Sitzung des beratenden Flüchtlingsausschusses am 12.2.1948.
} 
committee between native and non-native inhabitants was launched in 1949, including two representatives from each community. ${ }^{32}$ Unfortunately its records are lost but its existence demonstrates the fraught social environment of reconstruction. Complaints in the advisory committee focused overwhelmingly on housing, in particular rent disputes, landlord refusals to carry out repairs, and difficulties acquiring furniture. In 1951, an expellee representative said that, 'If the terrible living conditions remain like this, the expellees will become asocial. ${ }^{33}$ Committee records offer insight into daily-life conflicts in Dortmund. In one such incident, native youth demanded that expellee youth leave a dance hall in Dortmund. This discriminatory treatment of adolescents made committee members especially indignant. Another example comes from a report about Mengede, an important city suburb, where 'refugees complain of the little interest that the native people have for the fate of refugees. ${ }^{34}$

\section{Managing the Politics of Inter-Community Resentment}

That city leaders took inter-community tensions seriously is documented in a wide range of municipal speeches and administrative documents. They responded with a welcoming concept of city-citizenship that sought to bind migrants and native Dortmunders together in a concept of mutual obligation. Considerable rhetorical effort was expended in constructing a common history for expellees and natives to serve as a civil basis for integration in the 1950s. These discourses presented recent migration as the latest stage in a long history of Dortmund as a migration city reaching back to the nineteenth century.

In 1949, Social Democrats swept elections and Dortmund gained a reputation as a 'red city' that has continued, though weakened, up to today. At first, Social Democrats had competition from Communists and Christian Democrats, but Communists were in decline while the CDU settled into a loyal opposition by the early 1950s. For instance, the CDU and the liberal FDP voted to invest Henssler as mayor, often abstained or voted for Walter Kliemt, City Director (1955-1966), and at times voted for Dietrich Keuning, mayor (1954-1969) after Henssler died. ${ }^{35}$ On refugee issues, a Christian-Democratic councillor said in

$3^{2}$ SD, 100/o2, Niederschaft über die Flüchtlingsbeiratssitzung am 30.12.1948.

33 SD, 100/o2, Niederschrift über die Sitzung des Vertriebenenbeirats der Stadt Dortmund am 23.1.1951.

34 'Besuch der Flüchtlingslager', Verwaltungsbericht, 10 July 1953.

35 SD, 9o/o1 12, Niederschriften Ratsversammlung, 26.9.1950; 9o/o1 8, Niederschrift über die 1. Sitzung des Rates der Stadt Dortmund am Freitag, dem. 9. Oktober 1964; 9o/1 12, Niederschift über die 21. Sitzung des Rates der Stadt am Montag, dem 24. Oktober 1966. 
1953 that, "The accommodation of refugees is a community task and can never become a party monopoly. ${ }^{36} \mathrm{CDU}$ factional leader Willi Koch, himself an expellee, intervened as such in city council deliberations - for instance to pressure Henssler to use the term 'expellee' rather than 'refugee'. ${ }^{37}$ Henssler nominated Koch to lead the council's expellee committee, which Koch accepted. ${ }^{38}$ There was extraordinary continuity in all areas of government and administration until 1966, when Kliemt stepped down. Only in 1965-1970 did a generational turnover take place in city leadership. Social-Democratic hegemony meant a tight interlocking of politics and administration in postwar Dortmund, which enhanced the cohesion and coordination of local refugee policy.

Dortmund's largest expellee group came from Waldenburg in Silesia, today the Polish city of Wałbrzych. Dortmund adopted Waldenburg's 'Patenschaft'39 and hosted annual expellee congresses, the Waldenburger Heimattreffen, where attendance increased from over 10,00o in 1953 to 18-20,00o in 1963, the largest in West Germany according to Dortmund's city archivist. In 1966, the archivist, himself a Waldenburg expellee, cited the minuscule support in Dortmund for the Block der Heimatvertriebene und Entrechteten (B $\mathrm{HE}$ ) party, which achieved notable successes as an expellee party in the 1950s, as evidence of expellees' successful integration in Dortmund. He wrote,

That the integration [Einbindung] of refugees in their new surroundings took place relatively quickly, is to be traced back especially to the mentality of Westphalian and especially of the Dortmunder people, whose forefathers themselves often migrated from the German east during industrialisation (among others, coal mining). Also, politically the new citizens (Neubürger) were quickly integrated into the large peoples' parties (Volksparteien). ${ }^{40}$

Here the city archivist was redeploying migration narratives city officials had propagated in the 1950s. Kliemt, for instance, said in 1955 that,

Many Westphalian people participated in Eastern German colonisation, of whom a number migrated back to make a considerable contingent of

36 SD, 9o/o1 2/3, Niederschrift über die Ratsversammlung am 21 u. 22.4.1953

37 SD, 9o/O1 2/2, Niederschrift über die Ratsversammlung am 28. und 29.5.1951.

38 SD, 100/02, Niederschrift über die parlamentarische Flüchtlungsausschusssitzung am 20.1.1949.

39 For the wider history of the Patenschaften, see Andrew Demshuk, 'Godfather Cities: West German Patenschaften and the lost German east', German History 32:2 (2014) 224-255. 
those working in the coal mines. In the postwar emergency Dortmund $[\ldots]$ took a mass of people from the east, who with Westphalian warmth have become true Dortmunders and who already look with pride at their new home $[\ldots]$

Kliemt emphasised the arrival of Waldenburg coal miners in 1870 in Dortmund as genesis for a trans-city working-class solidarity centred around coal mines, trade unions, and of course the SPD, which had been the dominant interwar party in Waldenburg. ${ }^{41}$ Like the city archivist, a Waldenburg historian, Kliemt drew on his background in regional history to craft this inclusive rhetoric. Kliemt's 1948 doctorate, titled 'Labour Migration in the Rhineland until the mid-19th Century,' was a history of migrants in the Ruhr's coal-mining trade unions. ${ }^{42}$

A crucial vector in this trans-city solidarity was Paul Klambt, Expellee Council chairperson (1948-1961), former head of the Social-Democratic faction on Waldenburg's city council, and leader of the local expellee organisation Kreisvereinigung der Ostvertriebenen. He was central to expellee-municipal relations for 15 years. Born in Berlin, Klambt had lived in Waldenburg for 36 years until his expulsion in 1946, arriving then in Dortmund. When he died in 1963, local newspapers noted his nickname as 'father of the refugees. ${ }^{13} \mathrm{Klambt}$ had joined the SPD as early as 1895, was a member of the German metal workers union, and spent time in Dortmund in the 1910s as an engineer. On his own initiative, Klambt set up advisory sessions for newly arriving expellees in the 1940s, where he advised them on housing, education, provisions, and civil life in Dortmund. ${ }^{44}$ He was a fixture of organised refugee and expellee life, a bridge between Waldenburg and Dortmund, and his activities were strongly commemorated upon his retirement. In the Expellee Committee he often defended expellees and the municipality against complaints, rebuking colleagues on multiple occasions for underestimating the challenges city officials faced. A 1949 comment is illustrative:

41 Horst-Oskar Swientek, '18 ooo Waldenburger kamen neu in die Bundesrepublik', Verwaltungsbericht, 29 August 1958; Swientek, '8. Waldenburger Heimattreffen', Verwaltungsbericht, 24 August 1962. 'SPD schlägt Stadtrat Dr. Walter Kliemt für das Amt des Oberstadtdirektors vor,' Verwaltungsbericht, 12 November 1954.

43 'Letztes Geleit für Paul Klambt', Ruhrnachrichten, 7 August 1963; 'Vertriebene fanden bei ihm stets Rat,' Westdeutsche Allgemeine Zeitung, 6 August 1953.

'Zum 8o. Geburtstag von Paul Klambt', Waldenburger Heimatbote, 1 January 1957. 
$[\ldots]$ one always finds represented the point of view that as good as nothing is being done for the refugees. He is of the view, however, that the opposite is the case [...] the care of refugees in Dortmund must be seen as good compared to other cities and states $[\ldots]^{45}$

In 1954 he repelled complaints against Dortmund administrators,

In all of my lengthy experience [with the administration] I can state my great pleasure with only a ridiculously small number of exceptions that it is everywhere and always attempted [...] to grant the greatest justice to the proposals of the Expellee Council and of its individual representatives. ${ }^{46}$

Despite positive relations with municipal authorities, the council complained when the city refused to establish special administrative offices for expellees and refugees. For instance, the City Council's Culture Committee, upon the initiative of SPD city council leader, Ewald Görschop, rejected the council's request to create a special culture committee for refugee issues. ${ }^{47}$ Advisory council members also complained that the city's Refugee Office had barely any autonomy within the Social Office, but the City Director refused to build a refugee-specific family-care unit. ${ }^{48}$ Dortmund's administrative culture was guided by a 'traditional' Social-Democratic reticence against encouraging ethnic or communitarian particularism that Patrick Ireland identifies in later decades in Essen as well. ${ }^{49}$ The city also received extensive criticism in the early 1950s from the advisory council when it did not reach the legal quota of employing expellees and refugees in city administration. ${ }^{50}$ City officials were eager, though, to pressure the community bank Sparkassen to elect expellee board representatives and for refugees to join the local Chamber of Commerce. ${ }^{51}$ Their lack of savings, networks and access to capital led to

45 SD, 100/O2, Niederschrift über die Sitzung des Flüchtlingsbeirates am 3.10.1949.

46 WWD, K1 30.152, Paul Klambt, An die Vertriebenenbeiräte des Regierungsbezirks Arnsberg und an den Vertriebenenbeirat des Stadtkreises Dortmund.

47 SD, 91/006 5, Niederschrift über die Sitzung des Kulturausschusses am 24.4.1951.

48 SD, 100/o2, Niederschrift über die parlamentarische Flüchtlingsausschusssitzung am 14.4.1949; Niederschrift über die Sitzung des Vertriebenenbeirates der Stadt Dortmund am 27.4.1951.

49 Ireland, Becoming Europe, 63-74.

50 SD, 90/01 2/1, Niederschrift über die Ratsversammlung am 28. und 29.5.1951.

51 WWD, K1 30.151, Niederschift über die Sitzung des Vertriebenenbeirats in Dortmund am 25.2.1954. 
their clear underrepresentation as employers in Dortmund, with an estimate of only a dozen expellee-led businesses operating in Dortmund in $1951 .{ }^{52}$ The Chamber appointed an expellee to represent these businesses and supported efforts to raise capital specifically for expellee businesses but resisted changing its statutes to increase expellee participation beyond these measures, for instance by creating a special department for expellee businesses..$^{53}$

Official discourses contained elements of social control. City representatives met incoming refugees in the early 1950s, welcoming them with meals before guiding them to refugee settlements. ${ }^{54}$ They made sure to tell new arrivals about the difficult conditions in Dortmund, warning that, 'if [you] are not so content with [your] new dwelling as [you] hoped to be [...] [remember that] Nazi rule has caused the destruction of Germany' They sought to instill democratic norms as civic duty, asserting that 'Expellees have the duty to contribute in every way to building democratic institutions in Germany and Dortmund. 55 Notable is that the press complained about their exclusion from welcoming events, 'such that we have no opportunity to have ourselves a picture of the care and needs of the refugees. ${ }^{56}$ At the peak of Soviet-Zone refugee arrivals in 1953, Kliemt attended a refugee conference to address 'misunderstandings', where he said:

Dortmund has itself been greatly damaged by the impact of the war and cannot accommodate refugees in the manner that would be most desirable $[\ldots]$ The city is dedicated to the fastest possible integration [Eingliederung] of refugees. In terms of work this has been possible, but in terms of housing this has been tremendously difficult. Dortmund is the first city to have rented halls in previous years to erect mass accommodations for incoming refugees $[. .$.$] The city has had to expend considerable sums of$ its own resources. ${ }^{57}$

After promising food subsidies, Kliemt endured passionate complaints about housing conditions but also received praise for the quality of city services. Officials also spoke at Heimattreffen congresses, where they combined

$5^{2}$ WWD, K1 30.15o, Vereinigung der Industrie- und Handelskammern des Landes NordrheinWestfalen. An die Industrie- und Handelskammer zu Dortmund, 3 O November 195 . wwD, K1 2484, Dr Utermann I to Herrn Alfred Zinke, 14.8.1948; K1 30.151, Dr. Enste to Herrn Dr. Weber Betr: Vollzugsprogramm der heimatvertriebenen Wirtschaft, 17.9.1954.

54 'Die ersten Umsiedler trafen in Dortmund ein', Verwaltungsbericht, 20 April 1951.

55 '454 Flüchtlinge in einer Woche', Verwaltungsbericht, 25 May 1951.

56 'Ostflüchtlinge in Sälen', Ruhrnachrichten, 29 April 1953.

57

'Ostzonenflüchtlinge loben und klagen', Verwaltungsbericht, 1 May 1953. 
narratives of shared history with stern warnings that expellees pursue legitimate claims to return home without violence or revanchism. In 1966 an SPD councilman, introduced as 'an old friend of the expellees,' predicated expellees' return on 'an understanding with Eastern European peoples,' anticipating the national party's Ostpolitik..$^{58}$ Of many quotes we can highlight those of mayor Keuning in 1955, who told the congress repeatedly, 'no revenge or hate.' Titling his speech, 'Expellees should brother themselves with natives,' he said that 'expellees and refugees from East German territories [should] fraternise with local people after their economic integration has successfully concluded,' a revealing quote of how officials envisioned integration might occur. ${ }^{59}$ In 1959, an SPD councilman told the congress that,

120,00o refugees and expellees have become true citizens in Dortmund. Here there is no difference made between old and new citizens. As long as you cannot return home, you should feel at home in Dortmund, as though you were born here. ${ }^{60}$

Refugees received discounts on public transportation and free or subsidised tickets to local museums and cultural events. ${ }^{61}$ The city administration took a particular interest in children, subsidising their local education, and financing Christmas and summer holidays for refugee camp children. ${ }^{62}$ The city noted that many children arriving from the east could not speak German, and established special classes for language integration in schools. ${ }^{63}$ It regularly approved direct subsidies for living expenses for tens of thousands of refugees at a time. ${ }^{64}$

The city's most pressing effort-and largest expenditure-was housing. Accelerating construction was the only means of achieving the city's objective of equalising conditions for expellees and refugees on the one hand, and evacuees and local homeless populations on the other. Expellees and refugees

58 “'Tag der Heimat" im Westfalenpark', Verwaltungsbericht, 16 September 1966.

59 'Vertriebene sollen sich mit Einheimische verbrüdern', Verwaltungsbericht, 16 September 1955 .

6o 'Tag der Heimat', Verwaltungsbericht, 18 September 1959.

61 'Hilfe für Ostzonenbesucher', Verwaltungsbericht, 1 January 1954.

62 'Stadt führt Flüchtlingskinder aus dem Lagerleben in die Ferien', Verwaltungsbericht, 30 July 1954.

63 'Einrichtung von Förderklassen für aus den Ostgebieten zurückgeführte Kinder und Jugendliche', Verwaltungsbericht, 21 June 1957.

64 SD, 90 52, Betreff Darlehen an die Dortmunder Gemeinnützige Wohnungsgesellschaft m.b.H. für die Unterbringung von Sowjetzonenflüchtlinge, 4 May 1953. 


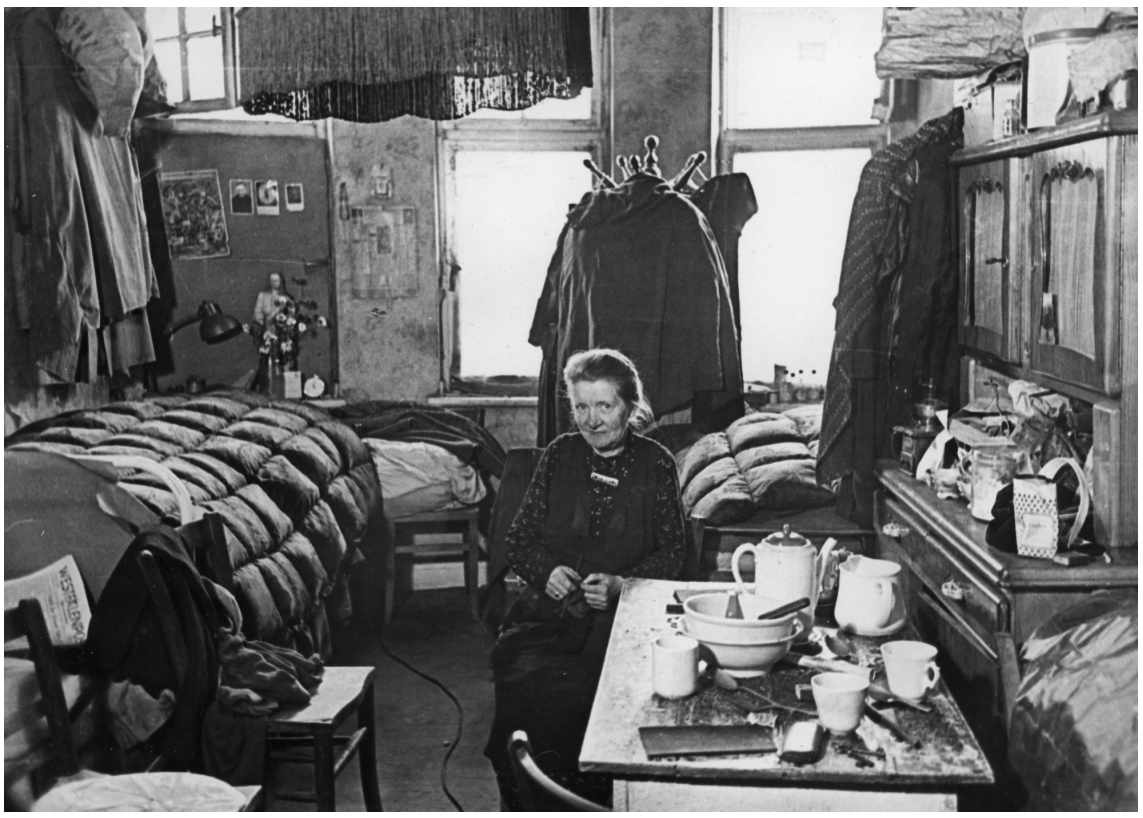

FIGURE 3 A single-room dwelling for 8 persons, typical of Soviet-Zone-Refugee housing in the mid-195os.

Courtesy of Dortmund City Archive, used with permission.

had legal privileges to newly available housing guaranteed by federal and state law, as they had in other areas of public life. This was all the more reason to build housing as quickly as possible so that there could be low-cost offerings for natives and returnees as well. The massive city-financed housing programme, launched in 1949, focused first on resettling inhabitants of 'miserable quarters,' before turning to camp residents on the city outskirts, and from 1957 to the homeless population for whom 'for 12 long years there was hardly anything done. ${ }^{65}$ It was a constant struggle. As soon as those in desperate need of housing decreased for the first time in $195^{2-53}$, Dortmund returned to crisis conditions with the arrival of tens of thousands of new Soviet-Zone refugees. The Social Office re-employed dozens of retired bureaucrats to cope with the increased workload. ${ }^{66}$ In $1953^{-54}$, Dortmund was operating 52 collective shelters, up from 14 in 1951, in addition to hundreds of 3-room dwellings housing 2 refugee families and 1-room dwellings cramming in 8 people. ${ }^{67}$

65 SD, 100/53, Niederschrift über die Sitzung des Sozialausschusses am 16.2.196o.

66 'Besuch der Flüchtlingslager', Verwaltungsbericht, 10 July 1953.

67 SD, 90 52, Dr. Kliemt, Unterbringung und Betreuung der Sowjetzonenflüchtlinge; SD, Sitzungsniederschrift über die Sitzung des Sozialausschusses am 24.9.1954. 
The primary strategy for integrating new arrivals - and lessening city expenses for their care-was labour market integration. The city had the legal obligation to receive a refugee quota from camps. It intervened with camp authorities in Siegen and elsewhere to pressure them to send refugees qualified for available jobs in construction and heavy industry. ${ }^{68}$ From 1951 municipal focus shifted to Massen, a camp on the southern outskirts of Dortmund, where more than 150,00o people were lodged between 1951 and 1958.69 The Labour Office asserted that no one would be obliged to work but, 'the greatest number [in Massen] are willing to work and ready to take any job. ${ }^{70}$ It posted available job openings weekly in Massen. ${ }^{71}$ City authorities and businesses competed with neighbouring jurisdictions like Hamm and Unna for suitable labourers among camp residents. This led to an internal dispute in $195^{2}$ with Dortmund's municipal transportation company, which refused repeated requests from the Labour Office that it run special services to compete with Hamm's busing of camp residents to work. ${ }^{72}$ City officials initially welcomed increased Soviet-Zone refugee arrivals in $195^{2-} 53$, but their numbers quickly overwhelmed temporary shelters. ${ }^{73}$ The city frantically built new temporary shelters in Mengede to meet incoming demand. Soon the labour market was saturated as well and the Labour Office requested in April 1953 that no more refugees be sent to Dortmund.

Local labour markets allowed rapid employment for those who matched industry needs. By $195^{8} 30$ per cent of coal miners in Dortmund had migrated from the east ${ }^{74}$ but the city's mono-industrial economy made labour-market integration of women, farmers, older and white-collar workers especially difficult. Female refugees had often been employed in textiles, but this industry hardly existed in Dortmund. Many migrants were reluctant to take jobs to which they were steered, for instance cleaning services for women and heavy labour

68 Landesarchiv Nordrhein-Westfalen (LNW), Abteilung Westfalen, N 100 Arbeitsämter, Agenturen für Arbeit, Nr. 4475, Arbeitsamt Dortmund, Abschrift, 18.12.1947.

69 'Der erste, aber schöne Zufluchtsort für Flüchtlinge und Umsielder aus dem Osten', Verwaltungsbericht, 6 November 1959.

70 LNW, N 100 Arbeitsämter, Agenturen für Arbeit, Nr. 4475, Arbeitsamt Dortmund, IIa3-5318, 15 July $5^{2}$.

71 LNW, N 100 Arbeitsämter, Agenturen für Arbeit, Nr. 4475, Arbeitsamt Dortmund IIb(m)-5318, Aktenvermerk, 23 October 1952.

72 LNW, N 100 Arbeitsämter, Agenturen für Arbeit, Nr. 4475, Dortmunder Stadtwerke Atkiongesellschaft, 3o July 1952.

73 LNW, N 100 Arbeitsämter, Agenturen für Arbeit, Nr. 4475, Arbeitsamt Dortmund IIal-5112/5318, 18 November 1952; Arbeitsamt Dortmund Ia2-1014, 8 May 1953.

74 '3900o kamen aus Schleswig-Holstein in den Ruhrbergbau', Verwaltungsbericht, 17 January 1958. 
positions for men. ${ }^{75}$ Concerned that refugees were less skilled than native workers ${ }^{76}$ and were 'especially endangered in the event of layoff', Dortmund's Labour Office policy was to lay out clearly the social interest of each refugee to the employer and prevent any eventual layoff.' 77 As new arrivals peaked in 1953, the Labour Director instructed that, 'All contact offices must do their best to quickly provide job referrals to Soviet-Zone Refugees' and 'Especially difficult cases should immediately be brought to [his] attention. ${ }^{78}$

A strong overlap between rhetoric and policy is indicative of the 'prevailing attitudes' shaping Dortmund's administrative culture. Officials emphasised mutual obligation, seeking to reconcile native Dortmunders with measures taken on behalf of expellees and refugees and to convince migrants that it was improper to protest material conditions in light of the suffering of native Dortmunders. Mayor Henssler warned in $195^{1}$ against evoking native resentment by excessively privileging expellees. He said,

I consider it self-understood that Dortmund will do its share to build a feeling of home for the expellees and repressed [...] but as the representative of a heavily destroyed city, which still has tens of thousands of its former citizens in evacuation who would like to return to their home city [...we should aim] to equalise conditions and not create a lasting difference between expellees and evacuees. I would regret if we play these victims against each other and that some gain the feeling that they are less worthy of rights and care than others. ${ }^{79}$

This mix of welcome and mutual obligation that Dortmund officials deployed in the context of expellee migration in the late 1940s-early 1950s extended as well to Poles and Soviet-Zone refugees. Both groups experienced local stigmatisation that the municipality worked to counter. Polish DP s were resettled in a new community in Dortmund-Eving in 1950-1951 funded by Marshall Plan and federal aid, for which locals quickly adopted the pejorative nickname 'KoreaTown,' in reference to the Korean War and, most probably, to the 'Eastern'

75 LNW, Arbeitsämter Nr. 830, Arbeitsamt, An den Herrn Leiter der Abt. II, 5. Juni 1953; Arbeitsamt Dortmund, Nebenstellen Lünen, an Abteilung II, 5 June 1953.

76 LNW, N 100 Arbeitsämter 830, Arbeitsamt Dortmund, 6.6.1953, Betrifft: Aufnahme von Sowjetzonen-Flüchtlinge.

77 LNW, N 100 Arbeitsämter, Agenturen für Arbeit, Nr. 4475, Arbeitsamt Dortmund, Abschrift bzw. Mehrabdruck. 19.8.49.

78 LNW, N 100 Arbeitsämter, Agenturen für Arbeit, Nr. 4475, Arbeitsamt Dortmund, Vfg, 24 March 1953 .

79 SD, Niederschrift über die Ratsversammlung am 28. und 29.5.1951. 
origin of the new inhabitants. Accounts are that neighbours treated the newcomers coldly and stigmatised them as criminals. ${ }^{80}$

A 1951 city bulletin article titled 'Foreigners find a new home' expressed a more generous perspective:

They are striving, despite their loyalty towards their guest country and their willingness to take over the same rights and obligations as apply to German citizens, to not have to fully give up their own people [Volkstum] and their own home and living manners. It is self-understood that the once so loved 'Germanisation' will not be attempted by German authorities or the German people either. Rather we are ready to allow foreign families their own life if they peacefully go to work and also integrate [einfügen] themselves into German civic life. ${ }^{81}$

The Association of Polish Refugees in Germany had established its headquarters in Dortmund and agitated for cultural autonomy and schooling in Polish for the community's children. ${ }^{82}$ For schooling, the article demanded, 'These children must find friendly acceptance in kindergartens.' The city set up four classes to instruct former DP children in Polish, with the goal that they would later join regular German classes. Though the municipality was more generous than the local community, it was probably beneficial for the settlement's inhabitants in the long-run that a majority moved out of Eving within a few years of arrival.

Dortmund's Labour Office was also rather tolerant of 'illegal' migrants (mostly from the Soviet Zone but also some former DPs). After tightening its practices to require formal employment papers during the hunger wave in 1948, it loosened its policy by 1951 to provide documents, urging that they be integrated into the local labour market. ${ }^{83}$ Dortmund's administration worked closely with Christian charities for the reception and care of SovietZone refugee youth. ${ }^{84}$ Kliemt himself considered 'the first task, spiritual care,

8o Evinger Geschichtsverein, 'Zwischen Ungewissheit und Zuversicht', June 2019, http:// geschichtsundkulturverein-eving.de/index.php/der-verein/6-nachruf-wagner.html, accessed 13 February 2021.

81 'Ausländer finden neue Heimat', Verwaltungsbericht, 5 October 1951.

82 Dietz-Görrig, 'Displaced Persons', 51.

83 SD, Niederschrift über die Sitzung des Vertriebenenbeirates der Stadt Dortmund am 27.4.51; Arbeitsamt Dortmund, Aktenvermerk! 9 December 1948; Arbeitsamt Dortmund IIa305318/545o, Aktenvermerk, 11.2.1953, N 100 Arbeitsämter, Agenturen für Arbeit, Nr 4475.

$84 \mathrm{~N}$ 10o Arbeitsämter, Agenturen für Arbeit, Arbeitsämter Nr. 83o, Letter to Herrn Stadtrat Dr. Kliemt, Sozialamt, 2 March 1954. 
to be of great importance'-'especially [for] morally and criminally endangered' youth. ${ }^{85}$ In response to a 1954 request from Berlin's administration, Dortmund's Labour Office declared its willingness to allow refugees who had not yet attained official status to come to Dortmund for work but asked first that they sign a form declaring 'I have been informed that I cannot count on receiving housing in Dortmund/Lünen in the foreseeable future. ${ }^{86}$

In the only significant city council controversy on migration in the 1950s, city leaders vehemently repelled a Communist Party attack on Soviet-Zone refugees. Seeking to take advantage of reconstruction-era problems to stoke discontent among natives and 'true' refugees, meaning expellees, Communists called for the council not to subsidise care and housing for new Soviet-Zone arrivals. Görschop responded, 'A word to the KPD: It would be welcome if you would stop saying that these people could have remained home. It is a sad sign that if people have different opinions from others that they must emigrate. ${ }^{87} \mathrm{~A}$ KPD councilman retorted, 'and here they are being locked up' in camps. During the suppression of the East Berlin workers uprising in June 1953, another KPD councilman said,

There is growing discontent among the people and the old refugees against these so-called new Eastern-Zone refugees and one asks why they are handled with special priority. It must be said that there was not a necessity for many of these Eastern-Zone Refugees to leave their homes. ${ }^{88}$

Here the KPD was playing on wider resentments in postwar German society. The treatment of Poles in Eving and a local businessman's letter to Dortmund's Chamber of Commerce indicate that such resentments existed in Dortmund: after calling 'the refugee problem' a disaster (Unglück) that would bring West Germany to 'catastrophe,' the businessman called for preventing 'us here from becoming flooded like Holland with seawater.' ${ }^{89}$ Expellee organisations also worried that the city would reassign resources to newer refugees. Klambt, for instance, expressed 'pessimism' to Kliemt in June 1953 about new housing

85 N 100 Arbeitsämter, Agenturen für Arbeit, Arbeitsämter Nr. 83o, Dr Kliemt, Sozialamt, Jugendamt to Herrn Direktor des Arbeitsamtes, 22 March 1954.

86 N 100 Arbeitsämter, Agenturen für Arbeit, Arbeitsämter Nr. 830, Der Direktor, Arbeitsamt Dortmund, 20.5.54.

87 Niederschrift über die Ratsversammlung am 21 u. 22.4.1953.

88 SD, 9o/o1 2/3, Niederschrift über die öffentliche Sitzung der Ratsversammlung am 16.6.1953.

89 WWD, K1 30.151, Hermann Krämer, Dortmunder Brennerei u. Lisoerfabrik, An die Industrieund Handelskammer Dortmund, 13 February 1953. 
projects for Soviet-Zone refugees, given expellees' continued difficulties attaining housing. ${ }^{90} \mathrm{He}$ appeared to question their refugee status as well, stating that of 57,0oo refugees who arrived in March-October 1953, only 1,00o fled out of fear 'of life and limb.' Inter-community tensions and complaints over assignments of new municipal housing were ubiquitous in the following years. ${ }^{91}$

Henssler responded that refugee status should be discussed in the Bundestag. 'We should not discuss this question because we do not have the possibility of influencing matters and to check the motivations of people who come to us.' For Henssler, 'What the KPD aims at with its proposals is nothing other than propaganda. ${ }^{92}$ A final quote from Görschop illustrates the SPD city leadership's strategy of harmonising the interests of all Dortmunders:

The Social-Democratic faction will do everything to mitigate the suffering of [Soviet-Zone] refugees. We want to help refugees to have a true inner feeling of having found a home. Also, we do not want to leave unmentioned that many of our citizens are waiting for a right to return to Dortmund. Some will never be able to see their home city again. They will die afar. We support whatever can be done and ask the administration to do all humanly possible. We will keep working so that the 25 ,00o people seeking housing steadily decrease..$^{93}$

\section{Post-Reconstruction: Guest Workers in 196os Dortmund}

In 1959 Dortmund began winding down social assistance for refugees. 'Integrated' (eingegliedert), as elsewhere in Germany, became an administrative category that marked the end of municipal social assistance. It was defined as 'integrated in a reasonable measure to one's previous economic and social relations. ${ }^{94} \mathrm{~A}$ municipal board to determine individual qualifications for continued social assistance included a local official, a refugee council representative, and a Chamber of Commerce member. A Social and Refugee

90 WwD, L 20.151, Niederschrift über die Sitzung des Vertriebenenbeirats in Dortmund am 25.6.1953.

91 WWD, K1 30.151, Niederschrift über die Sitzung des Beirates für Vertriebene- u. Flüchtlingsfragen am 15·7.1954.

92 SD, 9o/o1 2/3, Niederschrift über die Ratsversammlung am 3.2.1953.

93 SD, Niederschrift über die Ratsversammlung am 21 u. 22.4.1953.

94 WWD, K30.152, Der 'eingegliederte' Flüchtling hat keinen Anspruch auf die besondere staatliche Flüchtlingsfürsorge, Dortmund, 2o August 1959. 
office survey from 1969 indicates that removing refugees' social assistance was a lengthy process. ${ }^{95}$

Deindustrialisation's first rumblings in the 1958 coal crisis - followed by the last refugee camp's closure in 196o-marks the end of the reconstruction era in Dortmund. Indicative of a new era was a city bulletin headline that 'the Ruhr [was] no longer a magnet [for migrants], 96 as the number of residents dropped for the first time since 1945. The federal government also phased out its co-financing of municipal housing, placing a far greater financial burden on Dortmund where housing shortages persisted in the early 196os-as the city shifted attention to homeless populations. ${ }^{97}$ A conflict with NRW and federal officials followed. Dortmund officials published a report refuting an official calculation of housing needs that did not adequately consider overcrowding, which they argued led to underestimations (and underfunding) of local housing needs. ${ }^{98}$

Dortmund's population had risen from a low of approximately 350,00o in 1945 to 650 ,ooo by 1961 and the city forecasted 75 o,ooo or even 850 ,ooo residents by the 1980s. Such forecasts show that, despite their consciousness of the need to diversify Dortmund's economy, city officials did not foresee the scale of the structural crisis that was to hit Dortmund. In 1960 an estimated 66 per cent of workers were employed in mining and metal industries, and 77 per cent of employees were male (by contrast the West German average was 64 per cent)..$^{99}$ Labour market integration for women and older workers remained difficult, and Dortmund also had a high number of citizens with disabilities (18.3 per cent to a West German average of 12 per cent). For these reasons, Dortmund was exceptionally vulnerable to the industrial crisis that struck in the 196os. Its reconversion plans, focused especially on attracting electronic companies, were generally unsuccessful. A frontline of deindustrialisation, the city developed structural unemployment amongst the highest in West Germany, though out-migration to more prosperous areas of Germany maintained official unemployment low until the 1966-67 steel crisis. This context is why relatively few guest workers came to Dortmund in the early 196os.

The guestworker programme got off to a slow start in Dortmund, picking up only in the mid-196os with the arrival of Turkish workers, following the

95 WWD, K1 3 30.155, Sozialamt/Vertriebenenamt, Stadt Dortmund, 5 February 1969.

96 'Das Ruhrgebiet ist kein Magnet mehr', Verwaltungsbericht, 22 January 1960.

97 'Sämtliche Sammelunterkünfte für Flüchtlinge geräumt', Verwaltungsbericht, 10 June 196o.

98 Georg Wagner, Sozialstaat gegen Wohnungsnot: Wohnraumbewirtschaftung und Sozialer Wohnungsbau im Bund und in Nordrhein-Westfalen 1950-1970 (Paderborn 1995) 315-18.

99 'Die Beschäftigungslage in Dortmund', Verwaltungsbericht, 19 August 196o. 
relatively small number of Greeks, Italians, and Spaniards who came in the early 196os. The first reference to guestworkers in the city bulletin is the arrival of 110 Greek workers in $1960 .{ }^{100}$ The city manager estimated that during the 1966-67 recession the foreign-worker population had fallen from 24,00o to 14,000, before rising again to 20,000 in $1969 .{ }^{101}$ Greeks and Italians were far more likely to return home during the recession than were Turks, such that by 1970 the guestworker population had converted from majority Southern European to Turkish. Few Yugoslavs came to the distressed city following the 1968 German-Yugoslav labour agreement, preferring more prosperous parts of Germany. In 196710 per cent of the unemployed receiving city assistance in Dortmund were guestworkers, suggesting that they were particularly vulnerable to being laid off as this proportion far exceeded their presence on the local labour market. During this severe downturn, city officials advocated humane treatment of guestworkers. In 1967, Dortmund's Labour Office Director Gerhard Ahl met with neighbouring Ruhr administrative officials, welfare representatives, employers and trade unionists. The conference rejected 'administrative force' to deny the renewal of workpapers and called for administrators to pursue 'humane contacts with foreigners through social care and help of every type.' Moreover, it 'appealed to the public to also treat foreign workers with understanding during this hard period of transition. ${ }^{102}$ The next month Ahl warned against 'too lightly gambling away' the labour potential of guestworkers during the crisis. 'We have the intention,' he said, 'to maintain a feeling of security for foreigners who stay here as long as they have their family here, participate in vocational training, or have suffered a work accident $[. . .]^{103}$

Earlier in the 196os, city officials had appeared unenthused by guestworkers' arrivals. This reflected continuities in administrative attitudes towards expellee and refugee arrivals from the 1940s-5os as burdens (especially due to housing shortages), but that added reservations particular to the new migrants. According to the city bulletin, 'Administrators in the Dortmund Labour Office look with somewhat mixed feelings these days at the vacationers returning from their homelands in Italy, Spain and Greece. They fear that this circle of workers may have substantially expanded to include family members, who admittedly will not be proper for skilled work positions but will cause considerable

\footnotetext{
100 '110 griechische Arbeitskräfte kamen nach Dortmund', Verwaltungsbericht, 19 August 1960. 101 SD, 9o/o1 15, Rede des Oberstadtdirektors H.D. Imhoff zum Haushaltsplan 1970 in der Sitzung des Rates am 15.12.1969.

102 'Die ausländische Arbeitnehmer auf dem veränderten Arbeitsmarkt', Verwaltungsbericht, 3 February 1967 .

103 'Beratungsstelle für ausländische Kunden bei der Stadtssparkasse: Arbeitsamt berichtet über Gastarbeitersituation', Verwaltungsbericht, 10 March 1967.
} 
concern about how they can be housed here.104 In 1961, Kliemt remarked that out-migration from Dortmund was only compensated by incoming guestworkers, but he presented this in a negative light:

[...] this is only a weak substitute or consolation for our communal task because there are concerns, which will suffice here without deeper discussion/justification, because the employment of foreign labour brings additional tasks with it. Besides the policing efforts needed for these foreigners, there will also in the future be social-political tasks-especially in housing — above all, if foreign workers also bring their families with them.'105

As in the 1940s-50s, Dortmund officials perceived guestworker arrivals as burdens to be carried but, again like the reconstruction period, they did not

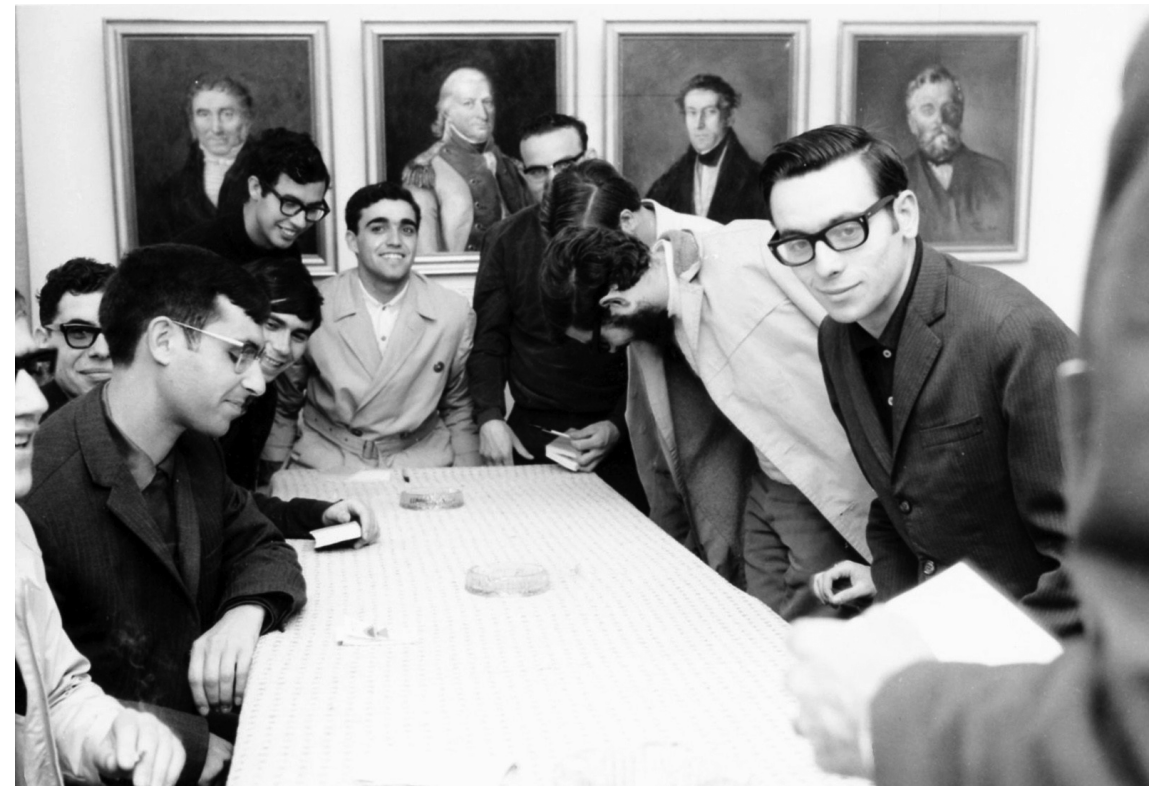

FIGURE 4 Guest worker housing in Dortmund at the iron and metalworking company Isselburger Hütte AG, courtesy of the Westfälisches Wirtschaftsarchiv, used with permission.

104 'Ausländische Arbeitskräfte kehren nach Urlaub zurück', Verwaltungsbericht, 1o November 1961.

105 SD, 9o/o1 7, Niederschrift über die 34. Sitzung des Rates der Stadt Dortmund am 16. Jan. 1961. 
stigmatise guestworkers or question their motives for coming. Rather they looked to accommodate them by redeploying earlier Social-Democratic discourses and policies. Though they opposed family reunification in the early 196 os and worried about strains on local resources, city officials took the initiative to translate city service documents, offering guidance on work, available housing, welfare, religious and social support, health, labour and social rights, and access to volunteers and translators. Further Dortmund officials arranged weekly consultation hours at the Sparkassen in Turkish, Greek, Spanish, Italian and Portuguese to assist guestworkers to open bank accounts, to organise weekly classes in Italian for guestworker children and to buy books and films in foreign languages for recreation. ${ }^{106}$ The Labour Office also paid for its administrators to take foreign-language classes to assist communication with guestworkers. There was initially hope that guestworkers would remain just that, guests, but the more generous administrative response discussed above to guestworker unemployment during the $1966 / 67$ recession shows that local officials were willing to adapt to new circumstances.

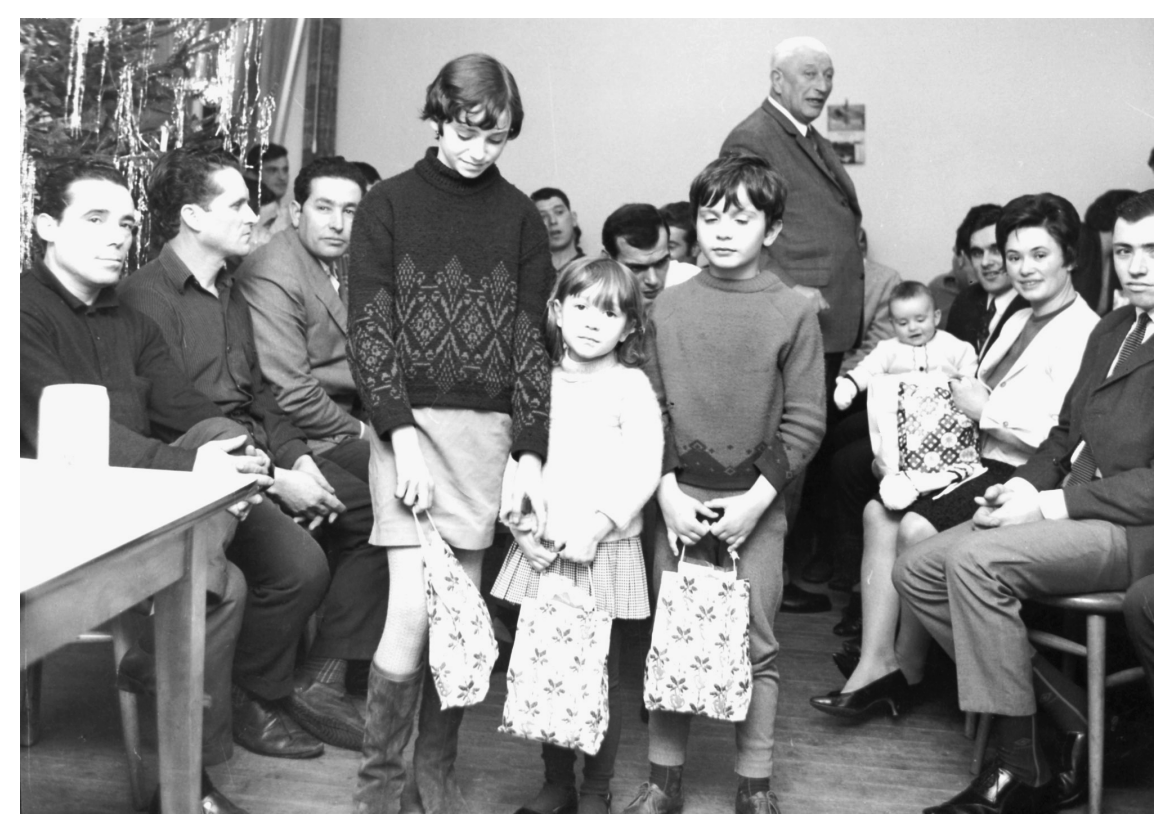

FIgURE 5 A Christmas celebration of Portuguese guest worker families in Dortmund. Courtesy of the Westfälisches Wirtschaftsarchiv, used with permission.

106 'Unterricht für italienischer Schulkinder', Verwaltungsbericht, 8 June 1962; 'Filmische Betreuung der italienische Gastarbeiter', Verwaltungsbericht, 27 June 1962. 
Turkish guestworkers began arriving in 1964. A Turkish football club formed to compete with other NRW football clubs of foreign players. In 1965 Dortmund co-financed a Turkish community centre with the federal and state governments and the local workers welfare society Arbeiterwohlfahrt, aligned with the SPD. For the city, it had the dual purpose that Turks 'feel at home' and bring Turks and other Dortmunders together. The city estimated that thousands visited the cultural centre, especially for folk music events. ${ }^{107}$ Local SocialDemocratic funders did not express any intention that the centre segregate Turks from local society, a function that Mark Spicka identifies for an analogous centre in Stuttgart. ${ }^{108}$ At the centre's inauguration, the representative of Dortmund's Arbeiterwohlfahrt said that,

it is necessary to bring the guests closer to the mode of life of Germans. They should become citizens of Dortmund City. There is great willingness for this among the Turks [...] The rooms should serve to build contacts with one another but also with German work colleagues [...]'

Further, the city bulletin wrote that 'these rooms should help familiarise Turkish guests with the lifestyles of the German hosts.' Dortmund's Social Office representative also said that the centre should 'serve as a meeting spot for all communities (die Gemeinsamkeit)'. These comments about bringing communities together closely echoed Dortmund's inclusive postwar narratives for expellees, refugees and other migrants. For instance, when the Dortmund Finance Office worked with youth charities to build a shelter in Eving in 1954 for 'homeless foreigners', they named it the 'House for Everyone.'109 The only comments at the ceremony emphasising an essentialist concept of difference came from a representative from Bonn's Arbeiterwohlfahrt who, unlike Dortmund officials, praised Turks for forming their own communal organisations. It is striking how his comments contrasted with the inclusivity expressed by Dortmunders:

There is a great danger for people who work in what [is] for them a foreign land. [...] There are negative consequences when they find social conditions in their host-land that are not present at home. [...] Besides, the Turkish government is of the opinion that its citizens after a certain

\footnotetext{
107 'Arbeiterwohlfahrt will praktische Hilfe leisten', Verwaltungsbericht, 17 March 1967.

108 Mark E. Spicka, 'Cultural Centres and Guest Worker Integration in Stuttgart, 196o-1976', Immigrants \& Minorities 33:2 (2015) 117-140.

109 LNW, L oo1 Nr. 5288, Friedhofen, Finanzbauamt Dortmund, 3 o April 1954.
} 
time will return again [...] The love and ties to the old home should be maintained and promoted among our guests. ${ }^{110}$

By contrast, Dortmund officials made no such remarks about cultural or social alienation. Nor did they present the Turkish centre as a site intended to maintain 'the love and ties to the old home' in order to prepare Turks to return. The Bonn official's comments make clear that such exclusive rhetoric was on hand if city officials had wished to use of it. Spicka's argument that cultural centres were intended for 'social control' in Stuttgart is likely valid for Dortmund as well but here it built on the city's inclusive policies from the 1940s-50s.

City practices were not only rhetorical but had real impact. Visiting Nuremburg officials noted with dismay the casualness with which Dortmund officials provided workpapers to foreigners who arrived on tourist visas from guestworker countries-a liberalism in keeping with earlier municipal practices to integrate 'illegal border crossers' into Dortmund's labour market.111 These administrative practices reflected the views of the city's SocialDemocratic leadership. In a city council discussion in 1965 about preparing a demographic survey, a CDU councilman spoke of an excessive number of foreigners (Überfremdung) in some occupations in Dortmund, referencing guestworker migration.

Marcel Berlinghoff highlights how the Überfremdungdebatte in Switzerland, in which Swiss media and politics swung against guestworker programmes, contributed to a "Europeanised" problematisation' of labour migrants with great influence on contemporary German debates in the 1960s. ${ }^{12}$ SPD councilman Günter Samtlebe certainly interpreted the comment this way. Samtlebe replied that,

[...] in his view there is in no way a danger of Überfremdung. A comparison with the guestworker problem in Switzerland is completely wrong. The Ruhr area has proved itself in the past to be the melting pot [Schmelztiegel] of all European peoples. ${ }^{113}$

\footnotetext{
110 'Begegnungsstätte für Türken und Dortmunder', Verwaltungsbericht, 24 December 1965.

111 Monika Mattes, 'Wirtschaftliche Rekonstruktion in der Bundesrepublik Deutschland und grenzüberschreitende Arbeitsmigration von den 1950er bis zu den 1970er Jahren', in: Jochen Oltmer (ed), Handbuch Staat und Migration in Deutschland seit 17. Jahrhundert (Oldenbourg 2016) 839-840.

112 Marcel Berlinghoff, 'Die Bundesrepublik und die Europäisierung der Migrationspolitik seit den späten 196oer Jahren', in Ibid., 937.

113 SD, 9o/o1 11, Niederschrift über die 5. Sitzung des Rates der Stadt am Montag, dem 22. February 1965 .
} 
Samtlebe's remarks are worthy of special note because a few years later he became Dortmund's mayor, a position he held from 1973 to 1999, continuing the long succession of postwar Social-Democratic rule. His reference to the Ruhr's migration history was a direct legacy of the welcoming discourses developed for expellees and other migrants to Dortmund during reconstruction. Whereas the politics on expellees and refugees had been largely consensual between the CDU and SPD, this exchange suggests that Samtlebe's application of postwar discourses of Dortmund as a melting pot to new guest-worker populations ran into greater resistance.

\section{Conclusion}

Five years after the Second World War, city leaders celebrated a birth to a refugee family, the 500,00oth resident of postwar Dortmund, as a symbol of the city's rebirth. Why emphasise such a mundane anecdote? First, city officials seized on this birth to emphasise how a refugee family had become Dortmunders, represented in physical form by a newborn, who inherently was a Dortmunder. The non-essentialist nature of city-belonging evoked by this little ceremony could not be starker. Second this inclusive rhetoric is indicative of city officials' 'prevailing attitude' towards expellees and refugees, as well as of other migrant groups, during reconstruction. Official discourses had particularist frames, drawing on history, class, and political culture to construct a narrative of historical fraternity between Dortmund and Waldenburg, the city of origin of Dortmund's largest expellee population. This particularist frame, though the most elaborated, did not detract from more universal frames of city-belonging that welcomed other migrants to Dortmund, the largest groups of whom were Soviet-Zone refugees, Poles, and, finally in the 196os, guestworkers. Particular and universal discourses of belonging drew upon and reinforced each other to solidify Dortmund's self-identity as a 'melting pot' city in the 1950s-6os.

The way city leaders and officials did this was to present everyone in reconstruction Dortmund-expellees, returnees, Soviet-Zone refugees, Poles, 'native' and evacuated Dortmunders living afar-as members of a common community of suffering. It was a municipal strategy that resurfaced again for guestworkers during the deindustrialisation crisis of 1966-67. City leaders were no strangers themselves to hardship. Mayor Henssler had spent ten years in concentration camps during National Socialism; Görschop had been arrested by the Gestapo. Though they rarely discussed their personal experiences, post-Nazi democratisation was existential for them and fed into the tone and 
content of their reception strategies for migrants. Combined with consistent rhetorical efforts to dampen and undermine the politics of inter-community resentment, the project included municipal efforts at social control, but, as far as can be gleaned from consulted materials, without the nefariousness often associated with the term.

The presentation of Dortmund as a migration city was a core element of the reconstruction politics practiced by Dortmund's Social Democratic Party. The findings compliment those of an oral history of expellees and refugees in the Ruhr in the 1970s: the author concludes that postwar migrants strongly contributed to the Ruhr's postwar 'social-democratisation,' which 'served again as a melting pot for natives and diverse ethnic and social groups.'114 Here we have focused on the agency of Dortmund's municipal authorities. Articles in this special issue on Mannheim and Stuttgart have shown quite different municipal attitudes than those that prevailed in Dortmund. Ireland's study on Essen and Hackett's on Bremen, by contrast, suggest that the dynamics on display in Dortmund may have reflected wider regional attitudes among Social-Democratic leaders in the Ruhr or perhaps even in Northern Germany more broadly, which had more welcoming policies than what we know from case studies of southern German cities. Dortmund's postwar history as a melting-pot city provides an example of the benefits of re-examining the contribution of the reconstruction period in the 1940-50s for our histories of local migrant integration in modern and contemporary Europe.

\section{Acknowledgments}

This article is part of the project 'Immigrant integration programs in European Cities from the mid 1940s to the 1970s. A comparative case study' funded by Jan Wallanders och Tom Hedelius stiftelse ( $\mathrm{P}_{17-0021)}$. The author would like to thank Hartwig Kersken, Klaus Pradler and Felix Bergmann for their generous and indispensable assistance in Dortmund.

114 Alexander von Plato, 'Fremde Heimat. Zur Integration von Flüchtlingen und Einheimischen in die Neue Zeit,' in Lutz Niethammer and Alexander von Plato (eds.), "Wir kriegen jetzt andere Zeiten." Auf der Suche nach der Erfahrung des Volkes in nachfaschistischen Ländern (Bonn 1985) 208-213. 